\title{
Effects of Teachers' Perceptions towards Physical Education and Sport in Selected Primary Schools in Kitwe District - Zambia.
}

\author{
Banda Martin $(\mathbf{P h D})^{*}$, Nalucha Gaudencia \\ University of Edenberg, Zambia
}

*Corresponding Author: Banda Martin (PhD), University of Edenberg, Zambia

\begin{abstract}
The aim of this study was to analyse the effects of teachers' perceptions towards Physical Education and Sport. Physical Education and Sport (PES) is an integral subject of Creative and Technology Studies at lower primary and Expressive Arts at upper primary in Zambian schools. Thus grade 1-4 and 5-7 respectively. Moreover, Physical Education and Sport is nationally examined in primary school at grade seven (7) still, as an integral subject of Creative and Technology Studies.
\end{abstract}

With regard to the methodology, the approach used was both quantitative and qualitative, with a research design being a survey design. Data was gathered by the use of interviews and questionnaires.

The target population was the head teachers and teachers. The sample size was ninety-nine, being five (5) head teachers and ninety-four (94) teachers. Purposive sampling was used to sample head teachers while systematic random sampling was used to sample teachers.

The findings of the study indicated that perceptions of teachers had both positive and negative effects towards the teaching of Physical Education and Sport in primary schools. As such teachers' perceptions played an important role in the teaching and learning process of Physical Education and Sport.

\section{INTRODUCTION: BACKGROUND}

Physical Education is an old subject in the history of Zambian education. According to Mubita (2017), the history of physical education follows the pattern of the history of education. Thus, the history of Physical education in Zambia can be divided into pre-colonial, colonial and post- colonial periods.

Pre-colonial education was practical in nature, allowing individuals to acquire knowledge and skills through exposure to the daily life activities with elders playing the role of teachers to the young ones.

The colonial period marked the beginning of formal education that led to the change in terms of structure and methodologies of teaching (Carmody, 2004). This led to the conception of PE as an academic subject.

Physical education continued as an academic subject after independence and up to date though it has suffered marginalization.

However, the education system in Zambia has gone through many reforms that led to several curriculum reforms such as the curriculum reforms of 2003 and curriculum reforms of 2013 among others. Each reform brought its own changes and development. The 2003 curriculum reforms attracted the first PE national examination in 2009 at grade seven (7) while the 2013 curriculum reforms included the aspect of sport to PE hence the use of two terminologies in the document Physical Education (PE) and Physical Education and Sport (PES.

\subsection{Theoretical Framework}

The study was guided by Bandura's Self-efficacy theory. Self-efficacy refers to an individual's belief in her capacity to execute behaviours necessary to produce specific performance attainments (Bandura, 1994). Self- efficacy reflects confidence in the ability to exert control over one's own motivation, behavior, and social environment. The basic premise of self-efficacy theory is the people's beliefs in their capabilities to produce desired effects by their own actions (Bandura, 1997).

Regardless of Physical Education Sport being a compulsory integral subject in primary schools, it has been anticipated that the teaching of PES depended on how individual teachers perceive the subject. It 
Effects of Teachers' Perceptions towards Physical Education and Sport in Selected Primary Schools in Kitwe District - Zambia.

is for this reason that the self-efficacy theory was opted, to explain the effects of teachers' perceptions towards Physical Education Sport in selected primary schools.

\section{LITERATURE REVIEW}

\subsection{Physical Education In Zambia}

\subsubsection{Physical Education in Zambia during the Pre-Colonial Period}

The pre-colonial man was unknowingly involved in physical education activities through daily life activities. PE was not thought of as an organized subject as we know it today (Kakuwa, 2005). Physical activities were mainly performed for survival.

Education remained unguided during the pre-colonial period with young boys and girls learning from fathers and mothers respectively through observations, imitation, and repetition (Snelson, 1974). Mufalali (1974) states that the fact that long before the Europeans set their foot in Northern Rhodesia, the natives were involved in physical activities such as wrestling, climbing, ox-racing, and traditional games. Thus, shows the presence of PE activities among the pre-colonial people. From this point of view, one can say PE during the pre-colonial period existed but in an informal. It was not structured as it is today.

\subsubsection{Physical Education in Zambia during the Colonial Period}

The arrival of missionaries in Northern Rhodesia (Colonial Zambia) brought about many changes in many aspects of life among Africans including education. Colonial Zambia saw the coming of formal education. The missionaries were the first one to introduce formal education.

The missionaries had their own view about what should be acquired through education. Carmody (2004) points out that the colonial administrators gave little attention to education. At the time, PE was considered to be docile. However, Mubita (2017) indicates that in whites' only schools the teaching of PE was not emphasized, instead, games were. Mubita further argues that in mission schools and teacher training colleges, PE was timetabled but there were no specific teachers for the subjects especially in primary schools. He went further to say that one set back in the subject was the little or no emphasis on its teaching and what was popular was competitive sport, which was mainly for fitness.

\subsubsection{Physical Education in Zambia after Independence}

After Zambia gained its independence, education was more or less the same as colonial education (Simposya, 2000). Nothing really changed as the new republic inherited the colonial education system. PE at that time was part of the curriculum, though it was influenced by colonial education in many ways (Kapembwa, 2015). However, the teaching of PE was not encouraging. In most schools PE was considered as mere play on dusty grounds behind classroom buildings and often reduced to jogging (Kakuwa, 2005).

However, regardless of PE being part of the school curriculum, It was perceived as a subject that lacked measurement since it was not examined and standards could not be easily set to determine results (Kakuwa, 2005). Grunbaum et al (2002) argues that PE was not often perceived as an academic subject like Mathematics and Science.

Nevertheless, PES is remarkably, one of the subjects that have experienced major transformation. PE is now an integral compulsory and examinable subject at primary school level in the Zambian education system. This was made possible after the curriculum reforms of 2003 that attracted the first examination in October, 2009.

Meanwhile, regardless of the Zambian education system passing through several reforms that were meant to improve education in general, PE was and still marginalized especially in primary schools. Blair and Capel (2008) argue that generalist primary teachers do not perceive themselves to be adequately prepared to teach physical education. Morgan and Bourke (2008) claimed that many primary teachers would prefer not to teach PE at all. On the other hand, the actual teaching of the subject is dependent on the interest of individual teachers (Quality Physical Education Policy, 2017). Quality Physical Education Policy went further stating that teachers are not effectively teaching the subject in all primary schools. 
Having reviewed literature relevant to the intended study, it reveals that the available literature does not necessarily fill the gap about the effects of teachers' perceptions towards PE which is now referred to as PES. The knowledge gap will be the motivating factor to explore effects of teachers' perceptions towards PE in order to obtain useful data.

\section{Methodology}

The approach used was both quantitative and qualitative, with a research design being a survey design. A survey helped to reach to targeted respondents and ensured a more accurate sample in which to draw conclusions. Thus, it provided useful information that helped to analyze effects of teachers' perceptions towards PES in selected primary schools.

\subsection{Area of Study}

The study was conducted in Kitwe district, Copperbelt Province of Zambia. The study specifically sampled head teachers and teachers from five selected primary schools namely: School A, School B, School C, School D and School E.

\subsection{Sample Size}

The sample size consists of ninety-nine (99) participants. This includes five (5) head teachers and ninety-four (94) teachers sampled from the five (5) selected primary schools.

\subsection{Sampling Techniques}

Purposive and Systematic random sampling was used in this study to avoid having some bias. Purposive sampling was employed on head teachers because the researcher considered head teachers to have the required information, government circulars, curriculum documents, and policy documents regarding the teaching of PES generally everywhere across the country as well as in their respective schools. Systematic random sampling was used to select schools and teachers from the population.

\subsection{Data Collecting Techniques}

Data was collected using questionnaires, in-depth interviews and document review. Below are illustrations on how each data collecting technique was deployed.

3.4.1. Questionnaire was administered to ninety-four (94) teachers from all the selected schools. The questionnaire contained open-ended and closed-ended type of questions. Thus, the data collected was both qualitative and quantitative. Open-ended questions were used to get detailed perceptions and experiences about physical education and sport implementation in selected primary schools. Closedended questions were for gathering information that the researcher intended to get which could not be obtained using open-ended questions.

3.4.2 Interviews specifically the in-depth interviews were used to collect data from head teachers to get their experiences, views and suggestions on the status quo of PES in selected five (5) primary schools in Kitwe District.

In this case, interviews allowed flexibility in data collection since the researcher was able to simplify challenging questions for more clarity and even ask more questions depending on the context. Furthermore, triangulation was employed during data collection as a means to cross-validate data to be collected as well as to capture different dimensions of the same phenomenon. Thus through triangulation during the interviews, different questioning techniques was used to collect data.

\section{Presentation Of Findings}

\subsection{Effects of Teachers' Perceptions towards PES}

According to the study findings, respondents gave two categories of answers, positives and negatives. 
Effects of Teachers' Perceptions towards Physical Education and Sport in Selected Primary Schools in Kitwe District - Zambia.

\subsubsection{Positive Effects of Teachers' Perceptions towards PES (N=99)}

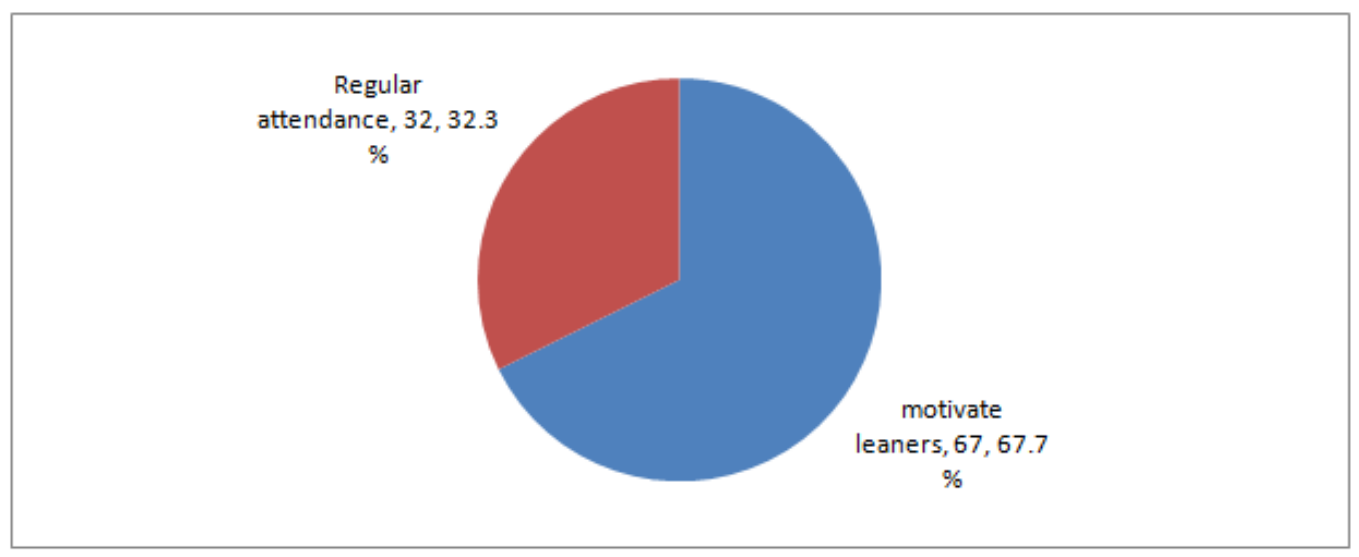

Source: Field Data (2019)

The study indicated that sixty-seven (67) respondents representing $67.7 \%$ indicated that positive perceptions of teachers towards PES motivate learners towards education as they look up to their teachers as /role models and promote good learner performance. While the remaining thirty-two (32) respondents representing 32.3\% indicated that teachers' perceptions towards PES promote regular school attendance of learners and a healthy happier learning environment that may contribute to having critical thinkers among pupils.

\subsubsection{Negative Effects of Teachers' Perceptions towards PES (N=99)}

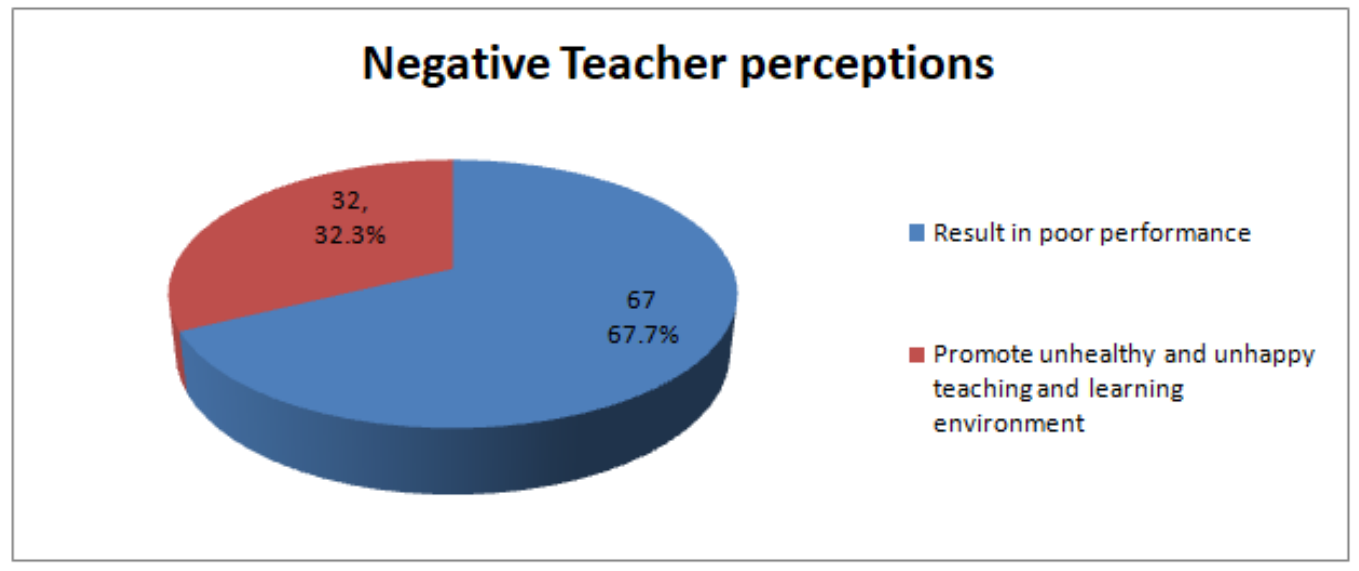

Source: Field Data (2019)

The study further indicated that sixty-seven (67) respondents representing $67.7 \%$ indicated that negative perceptions of teachers may result in poor performance by learners, reduced morale towards their education and thinking capacity in learners. While thirty-two (32) respondents representing 32.3 $\%$ indicated that teacher's negative perceptions promote unhealthy and unhappy teaching and learning environment,

\section{DISCUSSIONS OF RESEARCH FINDINGS}

\subsection{Positive effects of teachers' perception towards PES.}

The main objective of the study was to determine the effects of teachers' perceptions towards PES. The perceptions of teachers on education play a key role on how students learn, retain and apply knowledge, attitudes and skills (Almulla, 2015). The effects of teachers' perceptions can be either positive or negative.

According to the findings of this research, it was revealed that positive perceptions of teachers towards PES promote good learner performance. Good performance of pupils in school is an ideal situation every school would wish to attain. It is an outcome of learner assessment used to measure the progress of pupils in school. As such, learners are good source of information on the quality of teaching and learning in classrooms and the school as a whole. Thukur (2013) states that academic 
performance determines the future goals and objectives of students. In addition, the study by Kapur (2018) shows that teachers have an imperative role in influencing the academic performance of the pupils. Therefore, good perceptions of teachers towards PE promote good performance among learners. It is an indication that teaching and learning is taking place and is working towards attaining the curriculum objectives.

The findings of the study revealed that respondents confirmed that positive perceptions of teachers towards PES and education in general encourages learners to attend school regularly hence academic success among others. Generally, pupils who attend school regularly usually attain higher grades and enjoy school more. Regular school attendance pattern promotes the development of other responsible patterns of behaviour in pupils. Therefore, the attendance rate is important because pupils are more likely to succeed in academics when they attend school consistently. The findings of the research are in conformity with Hildebrand (2019) who asserts that the benefits of regular school attendance has many benefits such as promoting academic success, encourage positive social interaction, provide access to varied learning activities and programmes, increases pupil engagement in school and community services. He further adds that the benefits also include development of good work habits for future employment, allows for safe learning environment and increases completion rate. In the same vain, the findings of the study by Alborz et al (2000) also established that teacher encouragement appears to have a positive impact on learners' educational progress.

The study findings also indicated that good teachers' perceptions towards PES promote healthy and happy learning environment that may contribute to having critical thinkers among learners. This means a healthy and happy learning environment accords learners an opportunity to actively participate in the learning process. The findings are in consistence with a study by Weimer (2011) who asserts that participation is one of the those workhorse instructional strategies- easy to use , straight forward, expected and often quite successful at accomplishing a number of learning goals. The active participation of learners in PES gives them an opportunity to actively participate in physical activities. This is also in line with Stevens (2008) who puts it that physical activities has been linked to improved cognitive performance and academic achievement among school going children.

Furthermore, revelation of the study indicated that good teachers' perceptions towards PES motivate learners towards their education. The attitudes of teachers towards teaching and learning play a very important role in shaping pupils' way of thinking towards their education. Hardre et al (2006) had a similar view and asserts that teacher's own perception of their ability to influence motivation is derived from their feelings of competency, knowledge of and strategies for motivating students and relatedness with students.

Pupils usually look up to the attitude of teachers, how they perceive the subject. There is a view that teachers are regarded as role models especially in school. This means teachers as role models should inspire and encourage pupils to strive for greatness, live their fullest potential and see the best in themselves. Pupils should look at a teacher as a person to admire and someone they should aspire to be like. It is necessary to motivate pupils and help them recognise their areas of strength and weakness.

Findings of the research on the other hand indicated that positive perceptions of teachers towards PES promote a comprehensive school health environment that can benefits effectively to attain both school health and education outcomes since pupils will be encouraged to participate fully in PES activities. The study findings further indicated that teachers have a valuable contribution to make in the domain of physical activities and that teacher can be utilized as successful agent of change. A healthy school environment can effectively improve both health and education outcomes, and help students to be healthy, lifelong learners. In addition, healthy schools also support the development of many pupils' competences, such as critical thinking, problem solving, decision making, personal management, collaboration, and leadership. Berry (2002) reinforces the research finding by stating that school environment contributes to higher levels of educational performance.

\subsection{Negative Effects of Teachers' Perception towards PES.}

Teachers' perceptions towards PES can also have a negative effect on its teaching and learning. According to the revelation of the study, negative perceptions of teachers promote poor learner performance in school. Pupils tend not to be motivated by their teachers because of their negative 
perceptions towards the subject. This is reinforced by Matsagouras (2000) who puts it that it is well known that positive behaviours exhibited by teachers determine to a great extent their effectiveness in the classroom and ultimately, the impact they have on student achievement. Teachers are cardinal in the teaching and learning process. Basically the attitude of a teacher plays an important role in the performance of his/her pupils. If a teacher has a negative attitude towards a specific subject matter like PES, there is usually a great chance of his/her pupils to follow suit.

In addition, this research indicated that the other negative effect of teachers' perception towards PES is that it promotes absenteeism among pupils. The revelations of the study indicate that negative teacher perception promotes absenteeism among pupils because they fail to meet their educational needs. Absenteeism in school is the habit of staying away from school without providing a genuine or any reason for not attending classes. It is a truant behaviour that negatively promotes poor performance among pupils. However, it is the aim of every school to lessen, if not eradicate absenteeism among learners. The findings are in conformity with Shute and Cooper (2015), who opines that absenteeism is one of the most basic indicators of what extent the educational needs of students are met by schools. He went further to say, if the students are turning their back on the education they are provided, it means that we need to ask ourselves the questions "What is wrong in the education?" Is something happening in our schools and classrooms that distract students from education?" In addition, the study by Senyametor, Gyimah and Minadzi (2018) indicated that absenteeism does not only affect the learners' progression but also affects the teachers' ability to present a class work in a sequential and organised way.

The study findings further revealed that negative perceptions of teachers towards PES promote unhealthy and unhappy learning environment. In an unhealthy and unhappy learning environment, learners are denied the privilege to express themselves through physical activities whilst in school. School environment means the extent to which school setting promotes student safety and student health (Mishra, 2008). This is in line with the study by Stronge (2007) who opines learners' perceptions of school climate were related to specific motivational variables that have a significant implication for the development of self-regulated as well as a long-term involvement and interest in learning.

In addition, the finding of the study showed that school is regarded as a second home for pupils where they spend most of their days' time. For this reason, it is important that the school environment should be as health and friendly as possible to support teaching and learning. Schools play a vital role in developing and supporting pupils as they grow and learn in preparation for adult life. It is for this reason that OECD (2012) contends that school failure penalises a child for life. Every teacher, parent, administrator and school member want to see pupils succeed in school, and establish the knowledge, skills, attitude and readiness they will need in future as adults. PES in this case is considered as an integral part of school healthy. The knowledge, skills, values and attitudes acquired through PES programmes need to provide with strong foundation learners need to lead lives that are physically, emotionally, socially and mentally healthy. A health school environment can set pupils up for success in the classroom and beyond. Therefore, data collected from this research indicated that if negative perceptions of teachers tend to promote unhealthy and unfriendly teaching and learning environment, then the objectives of PES in school will not be achieved.

The data collected from this research indicated that negatives perceptions of teachers also reduce the morale of both teachers and pupils. Morale is more associated with a mental state which concerns with a person' confidence, hope and enthusiasm to participate in performing a task. It is a state of mind that involves feelings and emotions, created within a person (Maliyamkono and Manson, 2006).Morale in this regard involves the attitude and perceptions towards learning conditions, learning environment, classmates, teachers and the entire school. According to Evans (1998)'s point of view, morale is very important because he regarded morale as a spirit of a group that make members to succeed. That is to say if the morale of teachers and their pupils towards PES is reduced, chances of teaching and learning to take place are reduced. The ideas above are also in the same vain with Ramachandran and Shibu (2017) who states that morale has been proven to have a direct effect on good pupils, it is one of the cornerstone of schools. They further stated that poor teacher morale is a possibility of teacher disharmony and also effect smooth running of the school. 
The findings of the research acted as a wakeup call generally to all the research participants of this research especially the head teachers since they are the overall supervisors at school level. This is in line with Kapur (2018) who contended that research in education shows how to make provision of solutions to problems and that research is a systematic effort to acquire new knowledge in all disciplines. As indicated earlier the general view is that PES has not been given the attention it deserves.

\section{REFERENCES}

[1] Alborz, A. et al. (2009). The impact of adult support staff on pupils and mainstream schools. http://eppi.ioe.ac.uk/cms/Portals/0/PDF\%20reviews\%20and\%20summaries/Support\%20staff\%20Rpt.pdf? ver=2009-05-05-165528-197 Accessed 29/06/2021.

[2] Almulla, M.A. (2015). A Teachers' Perception of the Effects of Class Size on Teaching. International Educational Studies; Vol. 8; No. 12. 2015 https://www.researchgate.net/publication/284791117_An_ Investigation_of_Teachers'_Perceptions_of_the_Effects_of_Class_Size_on_Teaching Accessed 10/12/2019.

[3] Bandura, A. (1997). Self-efficacy: The exercise of control. New York: Freeman.

[4] Bandura, A. (1994). Self-efficacy. In V.S. Ramachandran (Ed.), Encyclopaedia of Human behaviour (pp. 71-81). New York: Academic Press.

[5] Berry, M.A.(2002). Healthy School Environment and Enhanced Educational Performance. https://www .ciriscience.org/a_314-Healthy-School-Environment-and-Enhanced-Educational-Performance Accessed $12 / 12 / 2019$.

[6] Blair, R. and Capel, S. (2008). Learning to Teach Physical Education in Secondary Schools: A companion to school experience. Routledge. London.

[7] Carmody, B. (2004). THE EVOLUTION OF EDUCATION IN ZAMBIA. Lusaka: Book world Publishers.

[8] Evans, L. (1998). Teacher morale, job satisfaction and motivation. London, Cassel.

[9] Grunbaum, J. A. et al. (2002).\|Youth risk behaviour surveillance-United States\| Journal of School Health, 72(8) 313-328.

[10] Hardre, P. L., Huang, S. H., Chen, C. H., Chiang, C. T., Jen, F. L.\& Warden, L. (2006). High school teachers' motivational perceptions and strategies in an East Asian nation. Asia Pacific Journal of Teacher Education, 34, 199-221

[11] Hildebrand, C. (2019) Te Importance of School Attendance. https://www.jrknightlynews.com/studentlife/2019/2/26/the-importance-of-school-attendance Accessed 01/11/2019.

[12] Kakuwa, M. (2005) Zambian Tradition Games and Activities. Oslo, Norway.

[13] Kapembwa, G. (2015). PERCEPTIONS OF PHYSICAL EDUCATION AMONG PUPILS IN SELECTED SCHOOLS OF LUSAKA DISTRICT, ZAMBIA. Masters Dissertation UNZA. Lusaka. Unpublished

[14] Kapur, R. (2018). Factors Influencing the Students' Academic Performance in Secondary Schools in India. https://www.researchgate.net/publication/324819919_Factors_Influencing_the_Students_Academic_ Perform ance_in_Secondary_Schools_in_India Accessed on 12/12/2019.

[15] .Maliyamkono, T.L. and Manson, H. (2006). The Promise. Tema Publishers Company Ltd. Dar-es-Salaam.

[16] Mastsagouras, H. (2000). Grop- Cooperation and Learning. Anthens: Grigoris.

[17] Morgan, P. and Bourke, S. (2008). Non-specialist teachers' confidence to teach PE: the nature and influence of personal school experiences in PE https://www.tandfonline.com/doi/pdf/10.1080/17408980 701345550 Acces sed 26/04/2019.

[18] Mishra, L. (2008). Teaching of Mathematics. New Delhi: APH Publishing Corporation.

[19] Mubita, A. (2017). A History of Physical Education in Zambia. Mongu College of Education. https:// www.researchgate.net/publication/321952808_A_History_of_Physical_Education_in_Zambia Accessed $01 / 06 / 2021$.

[20] Mufalali, I. (1974) Physical Education for Primary Schools. Lusaka: NECZAM.

[21] OECD (2012), Equity and Quality in Education: Supporting Disadvantaged Students and Schools, OECD Publishing. http://dx.doi.org/10.1787/9789264130852 -en Accessed 29/06/2021.

[22] Quality Physical Education Policy (2017). SITUATION ANALYSIS OF PHYSICAL EDUCATION AND SPORT IN ZAMBIA: Towards Quality. A Physical Education (QPE) Policy Framework. 
Effects of Teachers' Perceptions towards Physical Education and Sport in Selected Primary Schools in Kitwe District - Zambia.

[23] Ramachandran, S. and Shibu, N.S. (2017).A Research Study on School Teachers Morale and Involvements Job on Tamilnadu. IOSR Journal of Business and Management 83 (IOSR-JBM) e-ISSN: 2278-487X, pISSN: 2319-7668. Volume 19, Issue 9. Ver. VIII (September 2017), PP 34-38 http://www.iosrjournals .org/iosr-jbm/papers/Vol19-issue9/Version-8/D1909083438.pdfAccessed03/11/2 019.

[24] Snelson, P. (1974). Educational Development in Northern Rhodesia 1883-1945. (2nd ed). Lusaka: Zambia.

[25] Senyametor, F. Gyimah, E.K and Minadzi, V.M.(2018). Factors Affecting Pupils' Absenteeism at Felicormfort Junior High School (JHS) in Cape Coast, Ghana. Journal of Education and Learning; Vol. 7, No. 6; 2018 ISSN 1927-5250 E-ISSN 1927-5269. https://files.eric.ed.gov/full text/EJ1192373. pdf Accessed 12/12/2019.

[26] Steven, T. (2008).The Importance of Physical Activity and Physical Education in the Prediction of Academic Achievement https://www.researchgate.net/publication/257653079_The_Importance_of_ Physical_Activity_and_Physical_Education_in_the_Prediction_of_Academic_Achievement Accessed 01 /11/2019.

[27] Stronge, H.J. (2007). Qualities of Effective Teachers.(2nd ed) ASCD.

[28] Symons, C. (1997). Physical Education in the Contemporary Society. London: Terrece N Book Press.

[29] Thakur, G.R. (2013). A study of students Teachers' Perception about Performance Appraisal. https:// www.researchgate.net/publication/326979275_A_Study_of_Student_Teachers'_Perception_about_Perfor mance_Appraisal. Accessed 12/12/2019.

[30] Simposya, W.K. (2000). Education System in Zambia. How it developed since independence on the 24th of October, 1964. https://www.sambia.uniwuppertal.de/fileadmin/didaktik/sambia/Symposya_ Education al_Sys tem_in_Zambia.pdf Accessed on 01/06/2019.

[31] Weimer, M. (2011). Benefits of Getting Students to Participate in Classroom Discussions https://www. facultyfocus.com/articles/teaching-and-learning/10-benefits-of-getting-students-to-participate-i+n-classro om-discussions/ Accessed 01/11/2019.

\section{AUTHORS' BIOGRAPHY}

Gaudencia Nalucha, is a teacher of Physical Education, Social Studies and a specialist in primary education working for the Ministry of General Education (MOGE) in Zambia. She holds a Primary Teacher's Certificate, Primary Teacher's Diploma both from Kitwe College of Education (KCE), a Bachelor's degree in Education from The University of Zambia (UNZA) and a Master of Education in Curriculum Studies degree from Mulungushi University (MU). She is a part-time lecturer at University of Edenberg. Her research interests are in curriculum, physical education, citizenship education and educational leadership and management.

Martin Banda, is currently the Deputy Vice Chancellor of University of Edenberg-Zambia. He holds $\mathrm{PhD}$ and MA: Ed in Sociology of Education from the University of Zambia, a Bachelor of Arts with Education from the Catholic University of Eastern Africa. His research interests are in Sociology of Education, Education and Society, The Teacher and the Community, Sex Education, Curriculum studies and Teacher Education.

Citation: Banda Martin (PhD), Nalucha Gaudencia. "Effects of Teachers' Perceptions towards Physical Education and Sport in Selected Primary Schools in Kitwe District - Zambia." International Journal of Humanities Social Sciences and Education (IJHSSE), vol 8, no. 8, 2021, pp. 1-8. doi: https://doi.org/10.20431/2349-0381.0808001.

Copyright: (C) 2021 Authors. This is an open-access article distributed under the terms of the Creative Commons Attribution License, which permits unrestricted use, distribution, and reproduction in any medium, provided the original author and source are credited. 